\section{1. 投资の释済計算の目的}

企業が速いテンポで確実な発展をつつけ高い利益率を あげている時期には，企業の投資意欲は一段と盛り上り 企業体の内部で多くの投資案が検討されつつあるすので ある。新製品開発のための研究や設㣁投資, 現製品の品 質改良やコスト低下のための設備取替え投資，また增産 のための設備执大投資など企業の収益性をさらに高める ための投資案が意志決定をまっている。

今次大戦後 10 年に近い低迷の時代を過きると, 日本 の産業復興は先進の諸工業国が警暎するテンポで進行し た。化学工業界も技術導入によるるのが主であったとは いえ昭和 30 年ころから图 1 にみられるよ5に企業投資 はきわめて旺盛であり, 化学製品の生産額からみて世界 のトッブクラスに入る化学工業国に発展した。しかし, 技術面の問題は除いても資本の大半を外部資本に頼らさ るを得ない資本構成, 製品の需要市場の狭さ, これに拍 車をかける企業競争のはげしさなどから，戦後の企業投 資がすへて成功であったとはもちろんいえない。企業の 運命を左右するほどのあるいは一時的にも企業の衰運を もたらすような，誤った企業投資の実例をいくつかあげ ることができる。

設備に投下された資本は减価償却によって回収される とはいえ，長期にわたって企業内に固定化され企業の経 営構造, 経営成穦を決定してしま5性格をもっている。 企業競争のほとんどみられなかった時代では，投資の決 定は勘のみに頼ってもよかったが現在のよ5に企業競争 がはげしく設備費に巨額の資本を必要とする時代では， 投資の決定は正確度の高い資料にもとつく正しい経済計 算によらねばならない。

投資の判定のための経済計算はケミカルエンジニヤが 日常の業務として行な 5 装直や機器の最適選定などの， 比較的小額の資金ですむ投資にも同じょうにあてはまる 経凮計算の方法である。

\section{2. 収益性の判定要秦}

投資の意志決定は経営のトップクラスの責任である

* 昭和 39 年 7 月 27 日 受理

**大内新置化学工莱 (株)

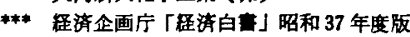

が，決定に必要な経済計算のための資料にはケミカルェ ンジニヤが担当すべき分野す多い。設備の建設費，製造 運転の経費, 製造原価などは, エンジニヤによって研究 の進展とともにくり返し推定計算が行なわれ，トップク ラスの意志決定の段階では決定を誤らせないだけの正碓 度をもつ推定值となっておらねばならない。同時に製品 の販売可能量中価格の予測, 資本の利子率, 所得税率之 の他の経済資料が販売や経理の部門から提出される。

これら経冏計算のための資料は投資後の将来に発生す る事態の予測であり，少なくとも設備の使用年数の全期 間にわたる予測であるので不確実な要素を多かれ少なか れ含む予測值である。ここに技術の不足からくる失敗の 危険とともに経済面での投資の危険性が存在する。企業 全般の経済計算が進んでいるフメリカにおいても，表 1

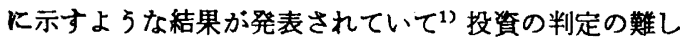

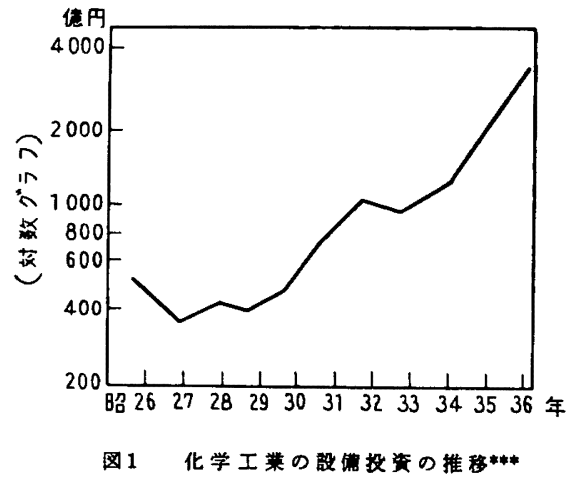

表 1

実収益と予測収益の差の実際例

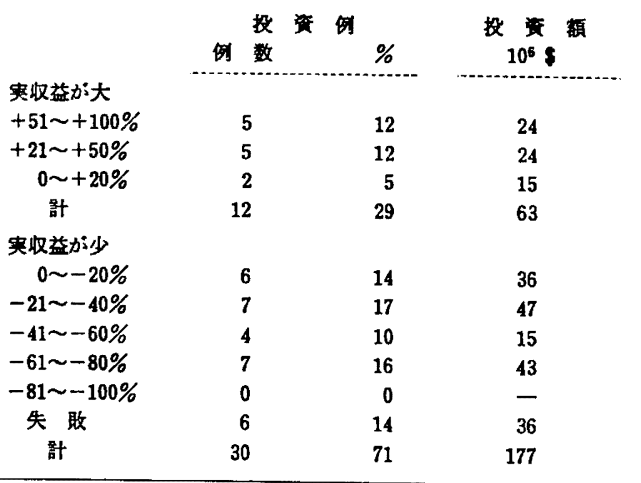


いことを示している。といっても不確実であるから投資 の経済計算は無意味であるとはもちろんいえない。

実際の収益が 予測収益より大であったのは投資例 42 例の $5 ち 12$ 例の $29 \%$ にすきず，投資額からみても $26 \%$ にすきなかった。反対に投資がまったくの失敗に終った 例数が 6 例もあり，実収益が予測収益より小さかった投 資が 30 例の $71 \%$ であった。また同じフメリカで新プラ ントの 1 年目の運転成績を調査したところ，100 例の ち 40 例が予測收益の半ば以下であった。いずれる投資 の収益性の予測の難しさを示している。

投資の収益性の予測には少なくとも表 2 にあげた各要 素について, 慎重な検討がなされなければならない2（土 ンジニヤが主として責任をもたねばならない要素を筆者 が○でかこんだ)。

右側の\%は設備の寿命が 10 年間とするとき，原著者 が推定する各要素の誤差範囲である。

設備固定資金，運転資金，設備の更新および維持費な ぞは，過去の経験や資料が豊富であれば高い正確度で推 定值がえられる。これらの推定計算はエンジニヤが行な ろべき計算であり，建設や運転の実績資料は推定計算の 資料として整理しておくことが大切である。

製品の需要量や価格が収益率にもっとも大きくひびく ので，困難な問題であるができるだけ正確な予測がなさ れなければならない。市場調査などの予測技術は現在ま だまだ末発達であるが，各企業ともこの方面の予測に大 きな努力を払っている。需要量の予測の誤りが価格の予 測の誤りより収益率に大きくひびくのが普通である。

製品やプロセスの陳腐化は企業が予想しない時期に発 生し、ひとたび発生すれば設備の運転休止や取替えなど の大きな損失を招くのが普通である。技術進歩の速い化

表2収益性に関係ある諸要素

\begin{tabular}{|c|c|}
\hline (1) & 設诵固定資金 \\
\hline (2) & 設備の建設期間 \\
\hline (8) & 正常運坛までの期咸と释 \\
\hline 4 & 製品の肘売量 \\
\hline 5 & 赀品の肘売価格 \\
\hline 6 & 減価壦却の方法 \\
\hline (7) & 設備更新资と椎持補炧费 \\
\hline (B) & 製品, プロセスの陳属化 \\
\hline 9 & 利益税率 \\
\hline 10 & インフレーション \\
\hline 11 & 资本の利子率 \\
\hline (12) & 運転资金 \\
\hline 13 & 製品に网する規制法律 \\
\hline (14) & 原料の利用度, 価格 \\
\hline (15) & 企莱競争 \\
\hline (16) & 設葪の残存価格 \\
\hline 17 & 危 険率 \\
\hline 18 & 利 益 積 \\
\hline
\end{tabular}

学工業では投資の判定時に陳腐化についても十分考えて おかねばならない。予測することは非常に困難であるが 陳腐化が起ったときに，どのように対処するかはあらか じめ考えておく必要がある。

企業が独占企業であるときは正常運転までの期間や経 費は収益性に余り影箁はなく，高い創業者利益をあげる ことができる。競争製品があらわれるととたんに収益性 にひびくので，镜争企業の動向も投資の決定前に十分調 査しておくべきとの一つである。

各要素については表 2 に示すよ 5 に推定予測の誤差籍 囲を推定値に付け加えておくことが望ましい。段資の判 定に際して重要な資料であり，楽観的な推定値ばかりで 計算した利益率が目標の利益率に達しないときは，その 投資案は全然考虑に值しないといえる。

\section{3. 判定のための経済計算法}

投資の可否や順位をきめるための経凮計算の方法は， これまで実に多くの方法が提出され使用されてきた。そ れらの方法す大きく分類すると，

1）原価比較法 (minimum cost method)

2）回収期間法 (pay-out period method)

3）利益率法 (rate of return method)

の三つに大別される。これらの方法はいずれる計算が比 較的簡単であり広く採用されてきたが，経済理論の発展 にともなってそれぞれの方法の欠点が明らかとなり，現 在では投資の判定基淮として金銭の時間的価值を計算に 入れた,

4) 利益割引率法 (discounted cash flow method) がもっとも合理的な方法とされている。4)の方法もさら に次の方法のいすれれかか目的によって使い分けられる。

4.1) 内部利益率法 (internal rate of return method)

4.2) 現在価値法 (present worth method)

1)，2），3）の方法も欠点があるとはいえ現在でもなお 経済計算の目的によっては広く使用されている方法であ るので簡単な説明を加えておく。

1）原価比較法 二つ以上の代替的な投資案がある とき，それぞれの原価を比較してもっとる原価の低い投 資案が有利であるとする方法である。

この方法は投資の収益性を明らかにしない欠点がある ので，収益が等しいかあるいは収益の差が無視できるよ らな代替案のとき用いられる。工場建設のような巨額の 資金を必要とする投資の判定には用いられないが，設備 取替えのための経済計算（たとえばMAPI 方式）や， 装㯰, 機器の選定のための経済計算などには十分使用で 
きる方法である。

2）回収期间法投資額を年間の利益額で割れば資 本の回收期間が計算され，投資金がある定められた期間 内で回収される投資のみを採用する方法である。

式で示せば,

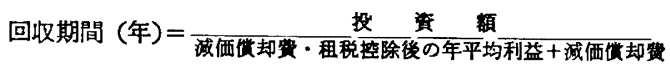

この方法も投資の収益性を示さない次点があるが，収 益性が注ば近い投資案では回収期間の短い投資を選ぶ方 法である。

外部資本や借入金の多い企業では資金の早期回収が経 営の安定のため重要な問題であるので, 収益性を示す方 法々併用すれば有効な方法である。

設備の減価償却費のように現金の流出をともなわない 支出はコストに入れないので, 耐用年数の短い設備投資 はその高率の償却費が利益に入り回収期間は短く計算さ れる。反対に耐用年数の長い設備投資は収益性が十分に 大きくても回收期間が長期となり，有利な投資案を見逃 す执それがある。

3）利益率法年間の利益額を投資額で割って投資 の利益率を計算する方法で, 回収期間の逆の計算である。 この利益率が企業の定めた最低の資本利益率より高い投 資を採用し，また利益率の大きさによって投資の順位を 決める方法である。

\section{式で示せば,}

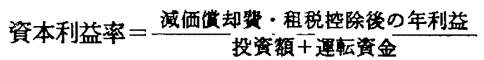

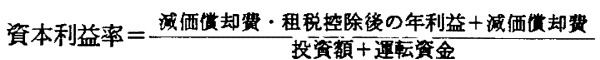

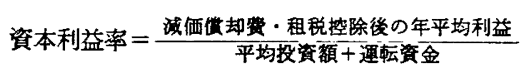

などの表わし方があり，同じ投資計画も計算者によって 異なる利益率が算出されるのがこの方法の欠点である。 しかし，投資額としては毎期の減価償却費によって投資 が部分的に回収されることを計算に入れた平均投資額を とり, 利益としては減価償却費と所得税を控除した年平 均の利益額をとる式 (4)を用いれば統一的な結果が得ら れる。

次に述へる利益割引率法に比べて計算が簡単であるの で，投資計画の初期の段階で計画の続行や停止を判定す るための簡易計算ではこの方法がよく用いられる。

投資の収益性を示す点でこの方法は合理的な投資の判 定方法といえるが，利益がいつ得られるかとい5時間的 要素が計算に入らない欠点がある。初年度以降の利益は とうぜ資金として再投資されてさらに利益をあげてい くので, 初年度以降の利益が每年同額であっても, 早い
年度の利益の方がより高い価值をむっているのはとうせ んである。この点を計算に入れたより精密な理論的な判 定基準が次に述べ 4) 利益割引率法 である。

4・1） 内部利益率法 投資によってあげられる年毎 の利益を現在価值に引きなおし, 現在価値の合計と現在 の投資額が等しくなるような利益率を計算する方法であ る。この利益率が企業の定める最低利益率より高い投資 は採用し，利益率の大小によって投資の順位をきめる方 法である。

いま最初の設備投資 $P$ 円の投資案があり，推定の設備 寿命 $n$ 年の間に初年度に $R_{1}$ 円, 以降毎年ごとに $R_{2}, R_{3}$, $\cdots \cdots R_{n}$ 円の利益が予測され, $n$ 年後の設備の残存価格 が $L$ 円と推定される場合の内部利益率を計算する。

利益 $R_{1}, R_{2}, \cdots \cdots R_{n}$ 円の現在価值は利益率を $i$ とす ると，

$$
\frac{R_{1}}{1+i}+\frac{R_{2}}{(1+i)^{-2}}+\cdots \cdots+\frac{R_{n}}{(1+i)^{-n}}=\sum_{1}^{n} \frac{R_{n}}{(1+i)^{n}}
$$

となり $1 /(1+i)^{n}$ を現在価值係数という。逆に現在の $P$ 円は $n$ 年後には $P(1+i)^{n}$ 円の価值となる。毎年の利益 額が等しいときは式 (5) は,

$$
R \sum_{1}^{n} \frac{1}{(1+i)^{n}}=R\left[\frac{(1+i)^{n}-1}{i(1+i)^{n}}\right]
$$

となり, $(1+i)^{n}-1 / i(1+i)^{n}$ を同一額毎期末厸現価係数 といい, この逆数の $i(1+i)^{n} /(1+i)^{n}-1$ を資本回収係 数という。 $n$ 年後の設備の残存価格が $L$ 円であればそ の現在価値は $L /(1+i)^{n}$ である。

以上から内部利益率 $i$ は

$$
P=R\left[\frac{(1+i)^{n}-1}{i(1+i)^{n}}\right]+\frac{L}{(1+\mathrm{i})^{n}}
$$

を満足する $i$ として試行計算法により求められる。

より精密な経済計算では運転資金 $W$ 円を計算に入れ る。製造をはじめるには設備固定資金と運転資金が必要 であり, 運転資金は製品の販売によって回転しているが, $n$ 年後に製造が停止したときこの運転資金は完全に回収 される。運転資金を計算に入れると，

$$
P+W=R\left[\frac{(1+i)^{n}-1}{i(1+i)^{n}}\right]+\frac{W}{(1+i)^{n}}+\frac{L}{(1+i)^{n}}
$$

を試行計算法で解いて内部利益率を求める。

式（7）あるいは式（8）を解くには $i$ と $n$ を変えて $(1+i)^{n}$ を計算した表あるいは図を用いればよいが，試 行計算は相当めんどうであるので図上から $i$ を簡単に求 める方法がいくつか提出されている。図2はその一つの 方法である3。式 (8) を変形すれば,

$$
\frac{i(1+i)^{n}}{(1+i)^{n}-1}=\frac{R}{P-L}-\frac{(W+L)}{(P-L)} i
$$




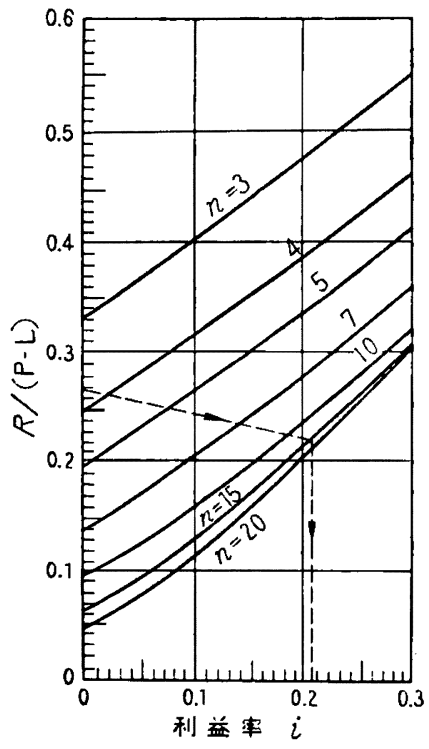

因2韵引利益率の出四

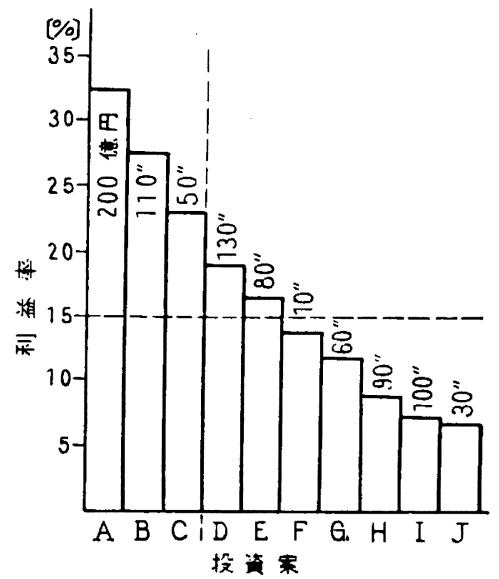

因3利益率に上る投觉の選択

となり，式（9）を基碟とした解法が図2である。本図 によれば $P, R, W, L, n$ が与えられたとき利益率 $i か ゙$ ただちに求められる。

設備固定資金額 $P=8,000,000$ \&, 運転資金 $W=$ $1,200,000$ \&, 残存価格 $L=500,000 \$$ で $n=15$ 年のとき

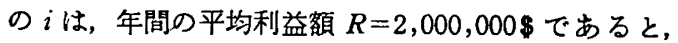

$$
\begin{aligned}
& \frac{R}{P-L}=\frac{2,000,000}{8,000,000-500,000}=0.2667 \\
& -\frac{W+L}{P-L}=\frac{1,200,000+500,000}{8,000,000-500,000}=-0.2267
\end{aligned}
$$

となるので絽軸の 0.2667 の点から傾斜が -0.2267 の直 線を引き， $n=15$ の曲線との交点から垂直に扰ろして $i=0.207$ が得られる。すなわちこの投資の利益率は
$20.7 \%$ ある。 $W, L$ が需のときす同様にして圀から が求められる。

4・2）現在価値法 将来の利益を全部現在価値に引 きなおし，それらの合計額と現在の資金額との大小を比 較して投資の可否をきめる方法である。現在価値に割引 く利子率は借入金の利子事あるいは慣用の利子率を越え る適当な利子事を資本コストなどを参考としてきめれば よく,この利子率が投資の目標利益率であるよ5にする。 毎年の利益額が等しいとき

$$
R\left[\frac{(1+i)^{n}-1}{i(1+i)^{n}}\right]+\frac{W}{(1+i)^{n}}+\frac{L}{(1+i)^{n}} \geq P+W
$$

が成立すれば，利益額の現在価值が資金額以上であるの でこの投資案は採用してよいと判定される。あるいは利 益の現在価值額と投資額との比が 1 以上のとき投資案を 可と判定する。

\section{4. 投资の判定基华}

設備投資を判定するための経済計算の方法をいくつか あけ゚てきたがすすでに説明を加えておいたようにるっと も合理的な判定基準は，利益の割引きをおこなった資本 の利益率を比較する内部利益率法である。その他の方法 は投資の規模や性質に応して補助的な判定方法として使 用される。

投資の決定を行ならとき利益率のほかに資金の調達の 可能な額と，資金が内部資金のみで十分であるか一部は 外部資金に依存せねばならないかも重要な検討項目とな る。利益金や減価傥却費などの内部資金を使用する場合 も，利子を計算に入れねばならないことは，内部資金を 他に投資すればとうぜんあげ得る利益をさしおいて投資 するからである。

いま多数の投資案 A，B，C，…がありこれらを利益 率の大きい順に並べると図3のよ5になったとする。企 業の定める最低の目標利益率が $15 \%$ であるとすると， $15 \%$ 以下の利益率しか期待できない $\mathrm{F}$ 以下の投資案は 採用されない。さらに研究を進めて利益率をあげる努力 をするか，市場の好転の時機をまつことになろう。

利益率からみると有利と判定される投資案も, 調達し らる資金の総額からの制約を受けるのはとうせんであ る。現在の資金調達能力は計画 $\mathrm{C}$ までの所要資金までで あるとすると，D以下の投資案も実施に移すことはでき ない。しかし，企業としては利益率が目標より高いD, $\mathrm{E}$ の投資案の実施について，借入れその他の資金調達に 努力するであろう。

投資のなかには企業競争に負けないために投資の利益 
率は低いが，梓争に敗れた場合の損失を総合的に判断し て投資にふみきる戦略的投資がある。また厚生施設に対 する投資のよ5に利益率を数字で表わすことはできない が、従業員の勤労意欲の向上を目的として投資すること あある。このような投資です投資による利益が大きいと 考えられるすのから投資するのはとうせんである。無形 の利益もできるだけ数字で表わすような方法をとる努力 が望ましい。

投資には多かれ少なかれ危険が伴らことは避けられな い。製品の品質の改良あるいはコスト低下のための投資 に類するすのは，投資の結果を高い正確度で予測できる のでもっとも危険が小さい。增産のための設備拡大投資 すコストは正確に予測できるが，とこまで需要が伸びる かに予測の困難があり危険が大きくなる。危険のすっと あ大きい投資はいうまであなく新製品や新しいプロセス の開発のための投資である。投資の決定にあたっては危 険の小さい投資は予測利益率が小さくてもよく（目標利 益率以上で)，危険の大きい投資注ど予測利益率が大き くなければならない。

1) C. Tyler: Chem. Eng., 69, Aug. p. 133 (1962)

2) H. C. Bauman: "Fundamentals of Cost Engineering in the Chemical Industry", Reinhold Publishing Corpora.

\section{5. むす ひ}

設備投資の経阂計算はもっとも有利な投資の選択を行 ならためのすのである。化学工業に扩ける設備には巨額 の資金が固定化され，一度建設されると製造量，製品の 品質やコストなど企業の成耫がきまってしまい，中途で 設備を変更するにはさらに巨額の資金を必要とするのが 一般である。したがって設備投資にはすっとる慎重な経 㧞計算がなされなければならない。

経済計算のための資料はすへて予測にもとつくあので あるから，できるだけ正確な予測を可能とする技術と過 去の経験を資料化しておく舫備が必要である。投資の判 定のための経䫆計算は多数の方法が行なわれてきたが, 金銭の時間的価値を計算に入れた利益割引率法がもっと る合理的な方法である。

高度の技術を必要とする化学工業ではとかく技術の面 に検討の重点がおかれて，経済計算をおろそかにしがち であることに十分注意せねばならない。

引用文献

tion (1964)

3) R. Salmon : Chem. Eng., 70, April p.79 (1963)

$$
\text { プロシェクト・エンジニアリングと最適化* }
$$

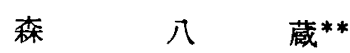

1. プロジェクト・エンジニアリンクの 定義と内容

最近プロジェクト・エンジニフリングといら言葉がよ く用いられる。従来は特にプロジェクト・ェンジニアリ ングを利用しなくても十分その目的が達成されていた が, 最近は大規模かつ複雑なJob が多く、それらに対し てはプロジェクト・ンジニフリングは必要欠くことの できないるのとなっている。

プロジェク・エンジニフリングとは

i） ある特定の Job を初めから終りまでなしとげる ためのエンジニフリングである。ブロジェクト・エンジ ニアリングは多数の Job を並行して処理して行く場合の

* 昭和 39 年 6 月 13 日 受理

**千代田化工建設 (株)
技術ではなく一つの Job をやりとげるための技術であ る。

ii）プロジェクト・エンジニフリングは

(a) そのJobができ上ったとき，その結果がより優れ たものであること。

(D) その Job をすすめて行く，そのすすめかたがより よいやり方であること。

上の二つが同時にもっともよく満足されるようにする ためのエンジニフリングである。別のいい方をすれば, プロジェクト・エンジニフリングとは, ブロジェクトの 最適化をはかるエンジニフリングであるということがで きる。

iii）プロジェクト・ェンジニアリングの対象となる 